\title{
A Circular Evaluation Tool for Sustainable Event Management - An Olympic Case Study
}

\author{
Csaba Fogarassy ${ }^{1}$, Balint Horvath ${ }^{1}$, Attila Kovacs ${ }^{2}$, \\ Linda Szoke ${ }^{1}$, Katalin Takacs-Gyorgy ${ }^{3}$
}

${ }^{1}$ Climate Change Economics Research Centre, Szent István University, Páter Károly u. 1, 2100 Gödöllö, Hungary

${ }^{2}$ Department of Operations Management and Logistics, Szent István University, Páter Károly u. 1, 2100 Gödöllö, Hungary

${ }^{3}$ Institute of Management and Organization, Óbuda University, Népszínház u. 8, 1081 Budapest, Hungary

fogarassy.csaba@gtk.szie.hu, horvath@carbonmanagement.hu, kovacs.attila@gtk.szie.hu, szoke.linda@fh.szie.hu, takacsnegyorgy.katalin@kgk.uni-obuda.hu

Abstract: This paper introduces a pilot project, which focuses on solar energy usage through the implementation of circular energy-sharing solutions, by event management. The conducted research examines the possibility of constructing a solar power park for a possible Olympic village. The study demonstrates a newly developed methodology which has been created to measure the circular efficiency of similar events. The analysis also elaborates on innovative business and technological solutions for developing solar energy schemes, which can be applied to circular principles and lead to further social-economicenvironmental benefits. According to the findings, the current energy infrastructure is not always suitable for improvement to higher development levels. The structure itself requires fundamental changes in order to enhance the sustainable and circular performance. Thus, pilot projects are required, as a first step, to implement similar technological and business salutations. In the case of earlier Olympics sustainable or carbon strategies, instead of long term planning, was important to focus for the short term thinking and management actions (carbon and ecological footprinting). The implementation of such novelties (circular principles), at highly anticipated events, could contribute to spreading closed structured, circular thinking in the future.

Keywords: circular economy; sustainable event management; circular economic value; solar energy park; energy cooperative; Olympic games; event management; renewable energy 


\section{Introduction}

In the case of previous Olympics' Carbon Strategy, not only the calculation of the carbon footprint was important, but also, its reduction [1, 2]. The carbon neutralization of the events can happen in two ways. During earlier Olympics, optimizing the material flow had an important role, by which their systems could manage a lower emission level [3, 4]. Furthermore, there are opportunities for offsetting the internal hazardous emissions. This method aims to compensate for inevitable GHG (Green House Gas) emission levels by financing mitigation projects in other geographical regions. After that, global climate policy mechanisms make it possible for the promoters to use 'carbon credits' to account them in the GHG balance of their event [5]. Finally, the third method, is to decrease GHG emissions, is to use clean renewable energy resources, which has already been applied during previous Olympics to make the games more sustainable $[1,2]$.

This paper introduces a pilot project which focuses on solar energy usage, through the implementation of circular energy-sharing solutions. The energy from the sun is one of the most popular renewable energy resources and its application becomes cheaper and more efficient annually. The price of solar systems decreases each year, which makes the financial indicators of related projects consistently better. The solar energy usage, of the European Union, for production of electricity, is currently low, at a mere $4 \%$ level. Only Italy, Greece and Germany are substantially different, where the amount of usage is around $7-8 \%$. However, in renewable markets, stakeholders are getting more interested, so current studies expect significant Solar energy development projects in the coming years [6].

This research is aimed at examining the possibility of constructing a solar power park for the possible Budapest 2024 Olympics, based on the principles of Circular Economy. By realizing that initiative, in Budapest, the Olympic village would be supplied, almost completely, by green energy, during the games. Even though the event was cancelled by the Hungarian government, the present study introduces an evaluation tool, which has been developed for the measurement of its sustainability. The Budapest 2024 Olympics was the first ever major event planned, in respect of Circular disciplines and the further elaborated methodology may easily be interpreted, to other event organization processes. Through the application of that novel circular tool and a cost-benefit analysis, the results show the improvements, in the project's material and energy flow that can be reached through the use of solar energy. Eventually, the analysis will introduce innovative business and technological solutions for developing solar energy, which can be applied to circular principles, and lead to further social-economic-environmental benefits. 


\section{Materials and Methodology}

According to previous experiences, the complete energy supply of the Olympics and the Paralympics cannot be realized entirely by renewable resources. The capacities constructed exactly for this purpose could only satisfy one part of the energy requirements from studies on prior Olympics [2]. This case study introduces a scenario, where at least $80 \%$ of the Olympic village's electricity supply is generated by a solar power park. The analysis is for the timeframe of the Olympics and the Paralympics, but the solar power park could obviously remain in the legacy period, and used as well.

The energy requirements of the Olympic village planned in Budapest were estimated based on data from the London Olympics. In London, the electricity demand of the Olympic village reached 4300 MWh [2]. The planned Olympic solar power park could sustain $20 \mathrm{MW}$ capacity on its own, which will probably require 40 hectares. However, due to efficiency increases for solar panels, it should need only half that space by 2020 . According to recent calculations, this equipment can sustain $80 \%$ of the estimated energy requirement (close to 3600 MWh). This naturally means that the remaining $20 \%$ would be supplied from the Hungarian energy production network.

\subsection{Calculating the Circular Economic Value (CEV)}

The circular efficiency of the system was measured by the circular economic value $(\mathrm{CEV})$ which was established for this very case study. The main aim of the methodology is to illustrate the effects of the renewable energy resource usage on the Olympics' energy- and material flow improvement. During the calculations, two scenarios have been distinguished. One is where the energy supply of the Olympic village comes from the domestic energy production networks which is usually employed (Business-As-Usual - $\mathrm{BAU}_{\mathrm{CEV}}$ ). The other is when the introduced solar power plant is realized, and the energy requirement is partially supplied by renewable energy resources $\left(\right.$ Scenario $\left._{\mathrm{CEV}}\right)$. The calculation method of the $\mathrm{CEV}$ is illustrated on Equation 1.

$C E V \%=100-\left(\frac{\left(\frac{M_{p}}{M_{p}+M_{s}}+\frac{M_{d}}{M_{r}+M_{d}}\right)+\left(\frac{E_{f}}{E_{s}+E_{f}}+\frac{E_{l}}{E_{c}+E_{l}}\right)}{4}\right) \times 100$ 
where:

$\boldsymbol{C E V}=$ Circular economic value

$\boldsymbol{M}_{\text {lin }}=$ Material volume on the input side (linear)

$\boldsymbol{M}_{\text {lout }}=$ Material volume on the output side (linear)

$M_{p}=$ The amount of primary raw materials used for the manufacturing of the product

$\boldsymbol{M}_{\boldsymbol{s}}=$ The amount of secondary raw materials used for the manufacturing of the product

$\boldsymbol{M}_{\boldsymbol{d}}=$ Amount of non-recyclable materials remaining after the product is used (linear) $\boldsymbol{M}_{\boldsymbol{r}}=$ Amount of recyclable materials remaining after the product is used (circular)
$\boldsymbol{E}_{\text {lin }}=$ Energy value on the input side (linear)

$\boldsymbol{E}_{\text {lout }}=$ Energy value on the output side (linear)

$\boldsymbol{E}_{f}=$ Amount of non-renewable energy used during the manufacturing of the product

$\boldsymbol{E}_{\boldsymbol{s}}=$ Amount of renewable energy used during the manufacturing of the product

$\boldsymbol{E}_{\boldsymbol{l}}=$ Amount of energy produced during disposal, after the product was used (linear)

$\boldsymbol{E}_{\boldsymbol{c}}=$ Amount of energy used for the product's recyclability, after the product was used (circular)

The description of the equation's parts contains a universal sample, which can be translated for any case. The main point is that it handles the input and output material and energy flows for systems, separately. The most important point is to describe the ratio between the linear and circular processes on the input and output sides.

\subsubsection{Analysis of the Material Side Indicators}

The analysis of the material flows required a thorough consideration of measures, since the whole study is basically about energy production networks. This means that the 'material' and 'energy' definitions cannot be subjects of confusion concerning the various sides. The material description elaborates on the nature of the material flow, regarding the produced energy in the BAU and Scenario versions. This indicator indicates the ratio of resource materials which aid the nonrenewable (linear) energy production on the input side. The output side focuses on the amount of the resource materials - that flow into the system - used during the energy production. This logic can easily be demonstrated through the efficiency problem of vehicles. As the vehicle only uses $18-25 \%$ of the fuel loaded into the tank for moving itself, the other part is lost for other operational mechanisms [7]. This is similar for the fossilized energy production networks of today, where a significant material loss occurs during the operation of power plants (Figure 1).

The Figure illustrates that the current energy production networks are far from operating efficiently. By the time the produced energy is consumed, the energy content of the system's material input is reduced to a fragment of the original. Therefore, the output side of the CEV takes the rate of energy losses - of used materials - in power plants into consideration. In the various energy production 
processes, waste (heat) energy has a huge role, which is produced in a higher amount then electric energy during electricity production. Table 1 introduces the energy conversion efficiency usually observed in the networks of the Hungarian energy mix.

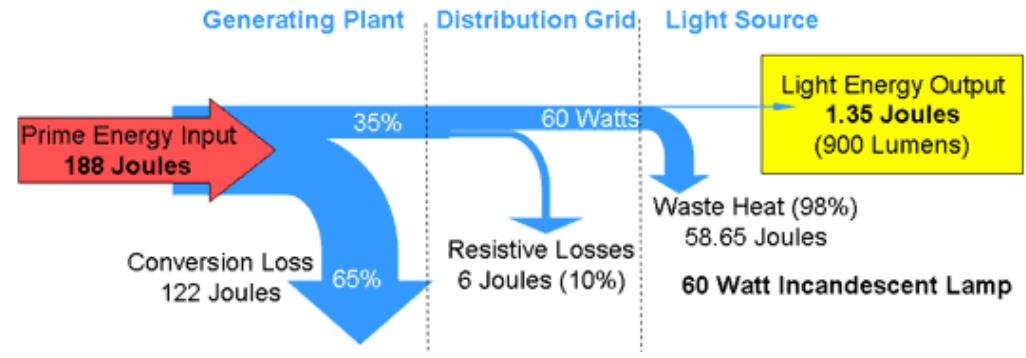

Figure 1

Energy loss observable during the lifetime of a light bulb ${ }^{1}$

Table 1

Energy conversion efficiency values of various technological solutions [8]

\begin{tabular}{|c|c|c|c|c|}
\hline $\begin{array}{c}\text { Year of } \\
\text { construction }\end{array}$ & $\begin{array}{c}\text { Gas- and oil } \\
\text { combustion } \\
\text { plants }\end{array}$ & $\begin{array}{c}\text { Coal- and } \\
\text { biomass } \\
\text { combustion } \\
\text { plants }\end{array}$ & $\begin{array}{c}\text { Nuclear } \\
\text { power plants }\end{array}$ & $\begin{array}{c}\text { CCGT } \\
\text { combined } \\
\text { gas) }\end{array}$ \\
\hline 1960 & $37.00 \%$ & $35.00 \%$ & $25.00 \%$ & - \\
\hline 1970 & $39.00 \%$ & $37.00 \%$ & $27.00 \%$ & - \\
\hline 1980 & $41.00 \%$ & $39.00 \%$ & $29.00 \%$ & - \\
\hline 1990 & $43.00 \%$ & $41.00 \%$ & $31.00 \%$ & $50.00 \%$ \\
\hline 2000 & $45.00 \%$ & $43.00 \%$ & $33.00 \%$ & $55.00 \%$ \\
\hline 2010 & $47.00 \%$ & $45.00 \%$ & $35.00 \%$ & $58.00 \%$ \\
\hline
\end{tabular}

\subsubsection{Interpreting the Energy Side Indicators}

As for the energy flow, the calculation is based on what ratio of the produced energy gets used during the phase after the material flow. In accordance with circular principles, the produced energy which does not fulfill its function of final consumption, contributes to linear processes. An important characteristic of current energy production networks is that their own operations require part of the energy they produce. Expert energetics literature calls this amount, selfconsumption [9]. Table 2 introduces the rate of self-consumption the energy production networks in the Hungarian energy mix have. The values in the table were included in the energy input calculation of the CEV.

\footnotetext{
${ }^{1}$ MPower UK - Energy Efficiency

http://www.mpoweruk.com/energy_efficiency.htm
} 
Table 2

Service and self-consumption of plants of different technological solutions [8]

\begin{tabular}{|c|c|c|}
\hline Plant types & Service percentage & Self-consumption \\
\hline $\begin{array}{c}\text { Gas- and oil combustion } \\
\text { plants }\end{array}$ & $90.00 \%$ & $5.00 \%$ \\
\hline Coal plants & $85.00 \%$ & $13.00 \%$ \\
\hline Nuclear power plants & $95.00 \%$ & $6.00 \%$ \\
\hline CCGT plants & $90.00 \%$ & $5.00 \%$ \\
\hline Wind power plants & $20.00 \%$ & $0.00 \%$ \\
\hline Biomass, biogas & $85.00 \%$ & $13.00 \%$ \\
\hline
\end{tabular}

The output side of the energy flow refers back to Figure 1. The figure clearly shows that apart from plant energy losses, there are further losses in the network. Therefore, there is merit in asking if this phenomenon will prevail for the solar power park planned for the pilot project as well. However, the solar power park planned for the Olympics will not only fulfill the role of a power source, but its geographical location will also have a significant role in circular planning. Unlike current centralized networks, its decentralized placement near the place of usage $(0-5 \mathrm{~km})$ will induce a minimal network loss $[10,11]$. For the energy output calculation, the 'Network loss' factor - signified by 'D' on Figure 2 - is required.

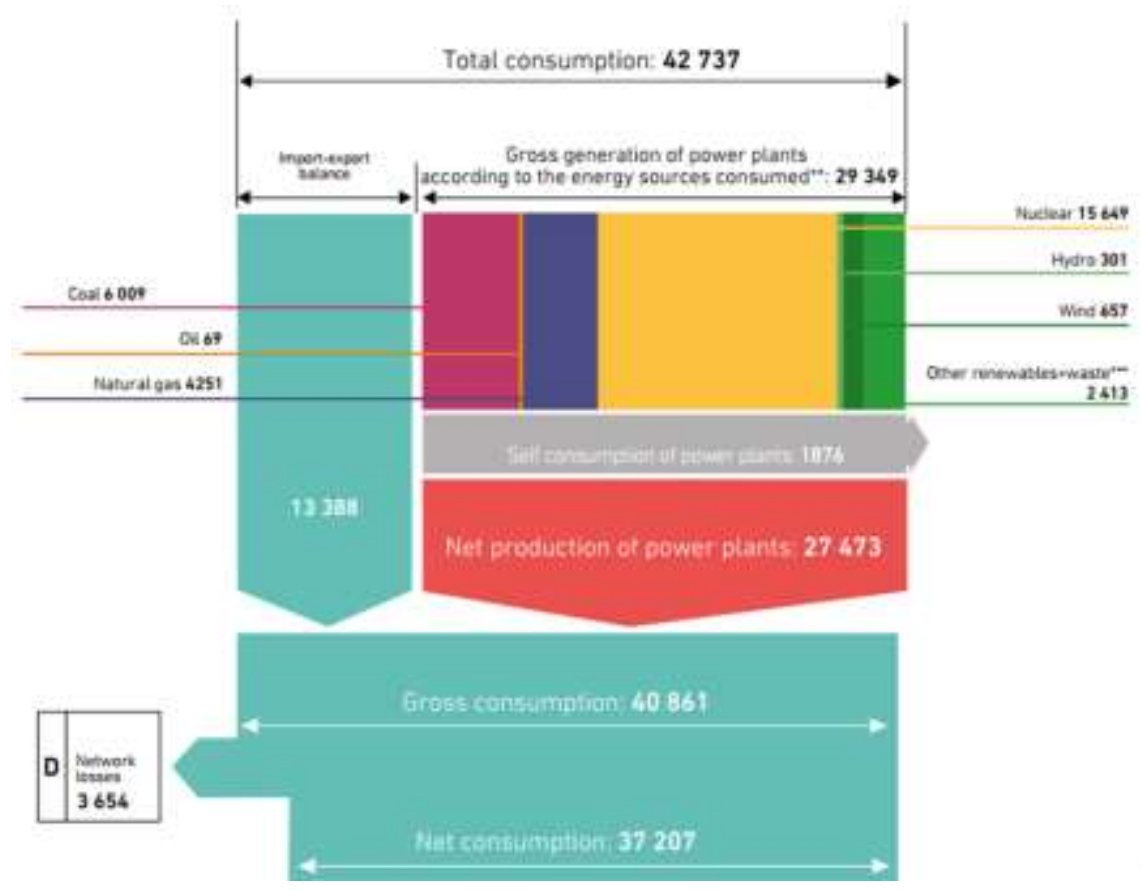

Figure 2

Electricity production and usage of Hungary (in GWh) in 2014 (incomplete) [12] 


\section{Results and Recommendations}

\subsection{CEV Values of the Olympic Village's Energy Supply Scenarios}

The circular economic values have been calculated for both the BAU and Scenario variants using the introduced criteria system. An important clause is that the Scenario version's solar power park can be used to supply only $80 \%$ of the Olympic village's energy requirements. Therefore, the Hungarian energy mix represented by the BAU variant (49\% fossilized, $43 \%$ nuclear, $8 \%$ renewable) also appears in the Scenario version, up to $20 \%$. It must be stressed that of all the processes (linear and circular) on the input-output sides regarding the materialand energy flow, CEV considers the share of linear processes. Therefore, components do not only contain the simple ratio of their indicator (e. g. selfconsumption, or network losses). These values were weighed with the intensity of their persistence, based on the technological solutions used in the variants. The indicators assigned to $\mathrm{CEV}$ components are the following:

- $\mathrm{M}_{\mathrm{lin}}$ : Out of the total amount of material usage, this represents the material volume used for linear processes.

- $\mathrm{M}_{\text {lout }}$ : Out of the total material losses, this represents the material losses during linear processes.

- $\mathrm{E}_{\mathrm{lin}}$ : Out of the total plant self-consumption, this represents the plant selfconsumption during linear processes.

- $\mathrm{E}_{\text {lout: }}$ Out of the total energy losses, this represents the energy loses in the network during linear processes.

Detailed and aggregated CEV values based on the factors can be seen on Figure 3.

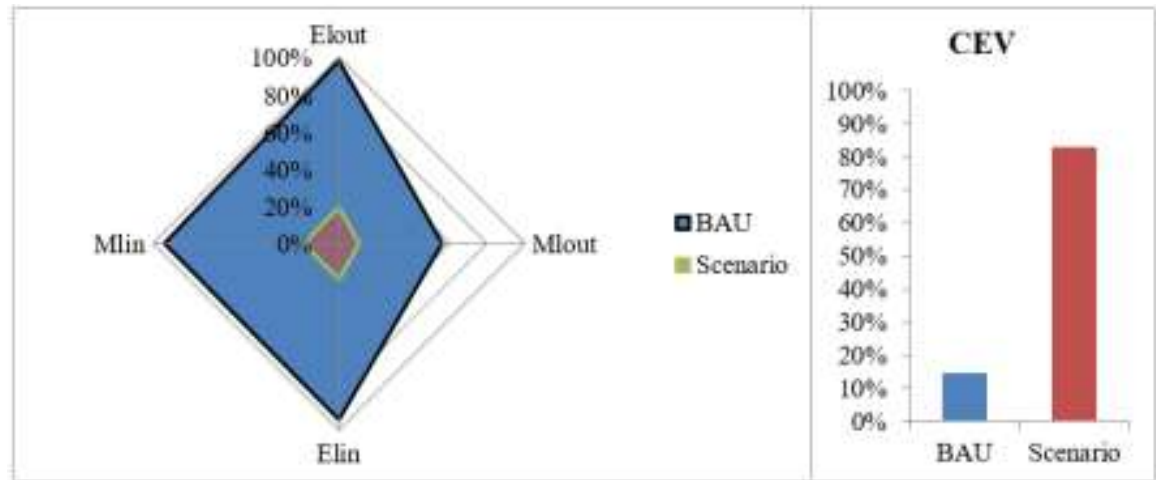

Figure 3

CEVs of BAU and Scenario variants, and illustrating their components 
The Figure clearly illustrates that the energy mix of the BAU variant only contains a scarce amount of circular tools $\left(\mathrm{CEV}_{\mathrm{BAU}}=17.3 \%\right)$. This is obvious, since merely $8 \%$ of the electricity production comes from renewable energy sources, which could improve these values. Contrary to this, the Scenario variant based on the Olympic solar power park is on a high level of circularity $\left(\mathrm{CEV}_{\text {Scen }}=85.5 \%\right)$. The lost amount can be accredited to the fact that the solar power park cannot supply the entire energy requirement, thus the scenario must employ the BAU energy mix for the remaining $20 \%$.

Perhaps the more important part of the analysis is not even the CEV of the Scenario variant. Renewable energy resources are already known to be on a high level of sustainability [13]. Seeing the values, it is no surprise that solar panels are the most efficient. For these technological solutions, linear processes are completely outclassed. The moral of this analysis is the BAU version, which apart from the Olympics - highlights an extremely important aspect. Nuclear energy is a supported process - even in some low-carbon concepts. Its energy is cheap and reasonably clean concerning GHG emission [14, 15]. However, in case of circularity, it does not stand so firm, as the analysis also proves. It employs linear processes, and the production of nuclear waste creates a massive amount of externalities (and their effects are not taken into consideration in many analyses) [16].

In order to see the entire picture for both the investment and operation costs - in case of both BAU and the solar battery-equipped Scenario - a cost-benefit analysis (CBA) demonstrates the related costs and profits to $\triangle \mathrm{CEV}$, which is the difference of the two CEVs $\left(\mathrm{CEV}_{\mathrm{BAU}}, \mathrm{CEV}_{\text {Scen }}\right)$.

\section{2 $\triangle$ CEV Cost-Benefit Analysis}

The first step of the CBA was to determine the average capital costs of $1 \mathrm{~kW}$ regarding Hungarian plant capacity. This makes up the BAU value. Then, it was compared to two different variants. On its own, it can be compared to only the capital values of the solar plant, and its corrected value. This latter follows the same logic as previous CEV calculations, which means, that these costs were compared to the quotient of the internal production and the network usage. The same principles were used for the repair and maintenance costs during operations. The other costs needed for the produced electricity were not accredited for, since the value of that would only improve the balance. The results can be seen on Figures 4 and 5 . 


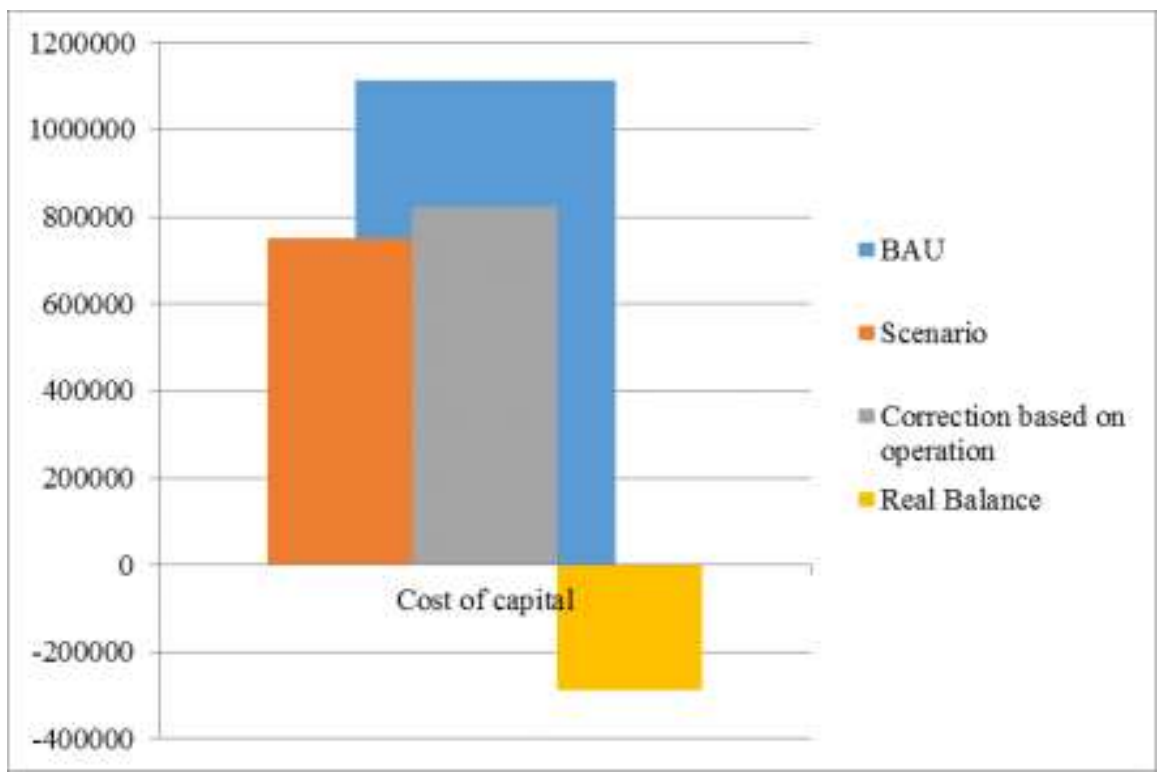

Figure 4

Capital costs of establishing $1 \mathrm{~kW}$ capacity

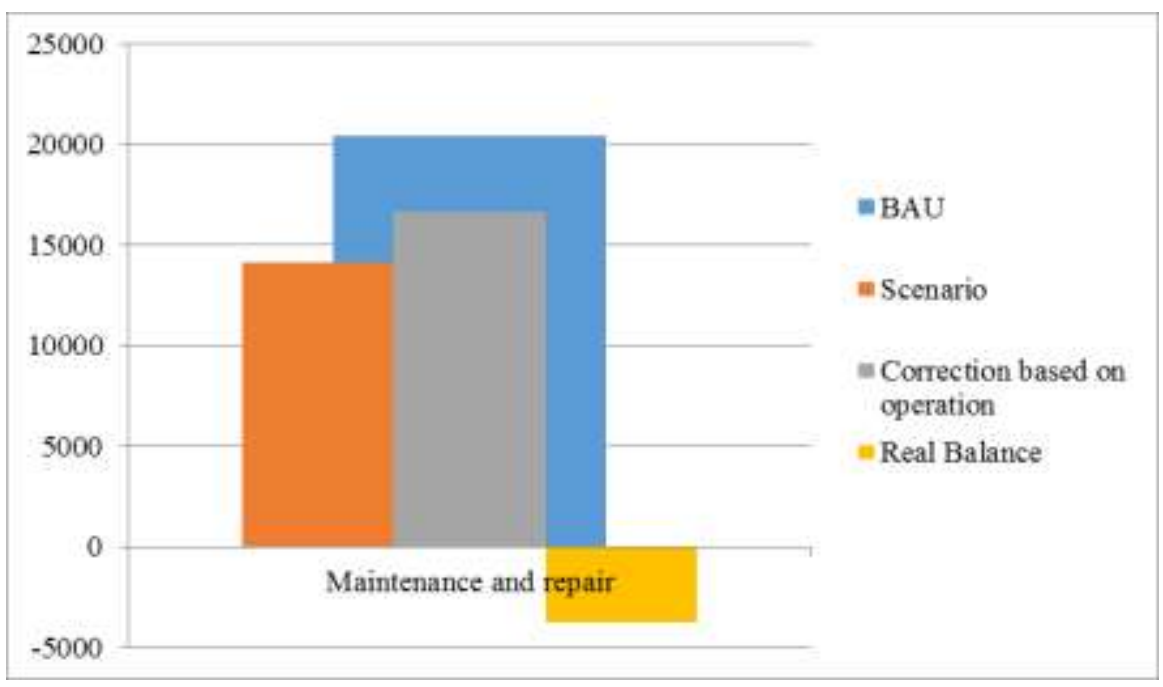

Figure 5

Comparison of annual maintenance and repair costs of BAU and Scenario for $1 \mathrm{~kW}$ capacity

As the results of the primary calculations show, the Scenario variant also comes with cost-efficiency compared to the domestic BAU economic values. In case of the capital costs, this means 288.392 HUF for each $\mathrm{kW}$ of capacity, considering 
the $20 \mathrm{MW}$ solar plant, whereas it causes 3.761 HUF of cost sparing in the case of the annual maintenance and repair factor, also for each $\mathrm{kW}$ of capacity established. Concerning the financial part of the calculation, the amount of savings are estimated to be $25.9 \%$ (from the cost of capital). In case of the operation, the capacity's maintenance costs would be $18.4 \%$ lower than in the original BAU value.

\subsection{Business and Technological Solutions Aiding the Circularity of Renewable Energy Networks}

So far, the analysis has mainly focused on highlighting attributes which could make the Olympic solar power park more circular. This, however, is still insufficient for a circular system innovation. The sustainable benefits of renewable energy resources were already well-known, the CEV analysis mainly translated these advantages to the language of circular economy. However, the circular concept means more than a simple 'exchange' in technological solutions. The question of 'how?' is much more important than that of 'what?'. While renewable energy resources had an important role in 'low-carbon' principles, the design of long-term, sustainable usage methods comes into perspective in case of circularity.

The usage of renewable energy resources is still shrouded in misconception, as far as society's knowledge goes. Though the studies published in the topic continuously stress the improving financial criteria [6] - apart from environmentally friendly effects - there are still barriers standing in the way of mass usage. In countries of lower incomes - even if the return indicators are improving steadily - people do not have the initial capital for such investments. Loan options or financing models for renewable energy developments are either non-existent, or they do not reach a wide range of society [17]. Concerning the western society, where people possess an advanced entrepreneurial mentality, there are other types of problems. In such countries, real estate is usually not owned by the tenant. In these life areas, tenement houses and flats are more widespread, meaning the tenants cannot install solar panels on the real estate, in contrast to their strong positive attitude towards them - since it is not their own property [18].

Gunter Pauli, the creator of the Blue Economy concept (one of the pillars of circular economy), described such uncomfortable situations as follows: "What we need in the first place is not technology, we need new business models that operate like ecosystems. If we can't design business models that offer what's good for you \& Nature cheaper than junk: forget sustainability!" His words clearly describe the position of green technologies. The solution is given, but the problem is that not many can afford it [19]. The newest western business trends do not reach exclusively towards new technological innovations, they rather prefer 
business model innovation [20]. This stands true for business models striving for not only economic but social and environmental sustainability as well [21]. The difference between the two is that while the former only aims at economic profit, the latter extends its value proposition to social and environmental horizons [22]. This study also tends to reach this goal for the Olympic solar power park. By using an innovative business model, the profits of this pilot project could reach a wider range of society.

\subsubsection{A Business Solution Aiming at the Social Aspect of Solar Energy Usage}

The story begins on a small Greek island named Sifnos. The inhabitants were fed up with problems persisting in the existing centralized energy supply. Such as, energy costs always surfacing and the perception that they are not the ones deciding the source of their energy. The local population could not afford the local, individual usage, of the renewable energy resources. This is when the idea of community energy production was born. Its essence is that the local community pools its resources to invest in projects, using renewable energy resources. In these cases, the volume of the investment is naturally greater which results in the establishment of a small-scale power plant. The legal description of the method, is called the cooperative form. This is where the name of the initiative comes from: Renewable Energy Source Cooperative (RESCOOP). The RESCOOP model began its march in Northern European countries, like Belgium or Denmark. An interesting point is that later, the Greeks themselves went to these nations to seek best practices. The key of success in these countries was the positive and supportive social attitude towards environment-friendliness. The communities were basically open to renewable energy, but they did not have the business model for realization [23].

Meanwhile, the example of RESCOOPs created 'spinoff ideas' which were never thought of by its creators. In time, the ideas of 'energy independence' and 'energy democracy' were spread, which were later integrated into the fundamental principles of the European Union. Their essence is that local communities create community renewable energy programs in a decentralized manner. This way, they gain the opportunity to choose the energy resource they want to make use of. Furthermore, as a cooperative, and as the owner of the resource, they can also determine the price of the produces energy [24]. In case they produce more than they consume, they can even sell it on the energy market - obviously, below the market price. The members of the cooperative can be natural persons, enterprises, municipalities and NGOs. During actual usage, the model can be formed at will. There's even an opportunity for the local community - in case of insufficient resources - to be in an investor role, instead of the owner of the project. The main point is the democratic principles of operation, during which all partial owners can state their opinions [25]. 
One such initiative has numerous economic-social-environmental advantages [26]. It creates new workplaces, boosts local economy [27], while decreases overhead costs - which are the greatest amount of costs the society has to bear - and increases the income people can spend at their convenience [28]. The environmental awareness of the populace improves [29], and due to the cooperative organizational form, they feel the pattern of energy closer to themselves, compared to when they are just customers of an external company (at higher costs). Concerning the Olympic solar power plant, it is also an important factor that the decentralized manner of the system can decrease network losses. Furthermore, renewable energy itself further decreases the self-consumption and the plant loss. This is how the material- and energy losses become much lower. The decentralized energy production offered by the RESCOOP business model is extremely compatible with circular principles which aim to avoid waste right at the first step of the life cycle.

\subsubsection{Smart Technology Applications for a More Efficient Energy Flow}

The application of smart technological solutions has been known in the field of energy production and consumption for quite a while. Italy was the pioneer of using smart measurement systems at the end of the 1990's [30]. By now, multiple European countries began to use them. Even more so, their widespread installation is among the short- and mid-term goals of the EU [31]. The essence of such systems is that they show the amount of energy usage in real time - unlike the traditional flat rate system. This way, the consumption trends can be followed more accurately which makes it easier to plan the energy production process. Furthermore, the splurging tendency of society also changes, if they can understand the costs of their behavior in real time [32]. Later, these served as the basis of the smart grid systems. On a unit level, they connect all energyconsuming applications of a household - which can even be controlled on the owner's remote controller tool. On a macro level, one obtains the opportunity to optimize the energy production systems. This process works best if the decentralized energy production spreads [33].

The description of the elaborated technological innovations clearly indicates that they all serve the efficiency improvement of energy production- and consumption systems. The traditional, centralized, flat rate mechanism caused a high amount of energy losses on the production side. On the consumption side, further negative effects surfaced. To supply over-consumption, additional energy production capacities' activity was required. Operating these systems offers electricity more expensive than the market price. Therefore, in the case of consumption peaks, some consumers pay much more for their consumed energy unknowingly. This phenomenon birthed the innovative initiative which may completely raise the world of efficient energy production. People of the United Kingdom came up with the 'Dynamic demand response' model based on the elasticity of the demand side of the energy market [34]. 
The concept is based on a future state, where smart tools and smart systems are installed. With their help, energy-consuming applications will be subjected to regulation, in order to continuously balance the supply-demand sides. In case of consumption peaks, the system tracks applications which may neglect energy for a short while. By turning them off, the demand stressing the energy production systems may be decreased. In other cases, like over-production, the intelligent system turns on applications, which serve as a sink for excess energy. The supplydemand balance of energy supply is an undying question for the energy market. The general practice is that at the time of peak demand, there is a need for extra energy production capacities. In case of supply peaks, the excess energy has to be rerouted, or stored. The extra capacities kept for either storing or rerouting are fossil-based, which impacts environmental indicators (even in the case of production systems basically using renewable energy) [35]. By balancing the production and consumption, a perfect energy circulation is created, which can be the future of energy systems.

\section{Conclusions}

The positive feedback of technology comparisons and circularity solutions introduced - based on the calculations - may serve as a sufficient basis for designing pilot programs for Olympic Games infrastructures. It can serve as an example for the modernization/optimization of the energy supply. An important aspect of sport event planning is to keep the built structures, in use, after the games, by analyzing the social dimensions of sustainability. Based on the introduced example, the solar power plant electricity supply may offer significant cost-efficiency improvements regarding the energy bills of the Olympic village. It can be purchased as an outside service, thereby gaining a place on the National Olympic Committees' subsidy sources. In case of the RESCOOP model, not only the GHG decrease or carbon-elimination obligations can be completed, but by converting the Olympic program into a social venture (meaning including small consumers into the realization of the investment), the economic sink-in of the sustainability problem could be solved as well. The owners of the Olympic establishments (Olympic solar power plant) would use the sports establishments powered by the solar power system for their own interests.

Therefore, the conclusion of the research is that climate and environmentally friendly technological solutions are highly compatible with the Olympics for the starting of pilot programs, if those are assigned to circular planning elements. The elaborated case study highlighted an important innovation possibility regarding energy systems. According to the findings, the current infrastructure is not always suitable to be improved to higher development levels. The structure itself requires fundamental changes in order to enhance circular performance. Thus, pilot projects are required, as a first step, to implement similar technological and business salutations. The implementation of such novel aspects, at highly anticipated/attended events, could contribute to growth in the future. 


\section{Acknowledgements}

This work was supported by The Budapest 2024 Bid Committee. The authors would like to thank the interested parties in the organization of the Budapest 2024 Olympic Games for their help and support.

SUPPORTED THROUGH THE NEW NATIONAL EXCELLENCE PROGRAM (for Linda Szoke and by the ÚNKP-17-3 for Balint Horvath) OF THE MINISTRY OF HUMAN CAPACITIES.

\section{References}

[1] Carbon Footprint Management Report Rio (2016) Olympic and Paralympic Games. 2014, Link: http://studylib.net/doc/18267806/carbon-footprintmanagement-report-rio-2016-olympic-and

[2] Carbon Footprint Study - Methodology and reference footprint - London 2012 (2010) Link: http://www.mma.gov.br/estruturas/255/_arquivos/carbon_footprint_study_r elat_255.pdf

[3] Veneroso, C. E., Ramos, G. P., Mendes, T. T., Silami-Garcia, E. (2015) Physical performance and environmental conditions: 2014 World Soccer Cup and 2016 Summer Olympics in Brazil. Temperature, 2 (4) 439-440, http://dx.doi.org/10.1080/23328940.2015.1106637

[4] Epstein, D., Jackson, R., Braithwaite, P. (2011) Delivering London 2012: sustainability strategy. Proceedings of the Istitution of Civil Engineers $\begin{array}{llll}\text { Civil } & \text { Engineering, } & 164 & \text { (5), }\end{array}$ http://dx.doi.org/10.1680/cien.2011.164.5.27

[5] Fogarassy, Cs. (2012) Karbongazdaság, L’Harmattan Kiadó, Budapest, p. 262

[6] SolarPower Europe (2016) Solar Market Report \& Membership Directory. Publishing Events Ltd, UK, Link: http://www.solarpowereurope.org/fileadmin/user_upload/documents/2015_ Market_Report/SPE16_Members_Directory_high_res.pdf

[7] Thomas, J. (2014) Drive cycle powertrain efficiencies and trends derived from EPA vehicle dynamometer results. SAE Int. J. Passeng. Cars - Mech. Syst. 7 (4), 1374-1384, http://dx.doi.org/10.4271/2014-01-2562

[8] Regionális Energiagazdasági Kutatóközpont (2010) A hazai végső energiafelhasználás és a villamoenergia-ár prognózisának elkészítése 2020-ig. Link:

http://www.hiletek.hu/index_htm_files/meh_energiafelhasznalas_vearprogn ozis_2020_rekk.pdf 
[9] Aragonés, V., Barquin, J., Alba, J. (2016) The new Spanish selfconsumption regulation. Energy Procedia, 106, 245-257, http://dx.doi.org/10.1016/j.egypro.2016.12.120

[10] Ochoa, L. F., Harrison, G. P. (2011) Minimizing energy losses: Optimal accommodation and smart operation of renewable distributed generation. IEEE Transactions on Power Systems, 26 (1), 198-205, http://dx.doi.org/10.1109/TPWRS.2010.2049036

[11] Fourie, J. W., Calmeyer, J. E. (2004) A statistical method to minimize electrical energy losses in a local electricity distribution network. $7^{\text {th }}$ AFRICON Conference in Africa, http://dx.doi.org/10.1109/AFRICON.2004.1406768

[12] MAVIR (2014) A Magyar Villamosenergia-Rendszer (VER) 2014. évi statisztikai adatai. Link: https://www.mavir.hu/documents/10258/45985073/VER_Stat_2015_1223 MAVIR.pdf/54105c7e-fc2e-439e-9779-5e468a28f5ae

[13] Farkas, F., Molnár, T. (2016) Recent applications of the renewable energies. Hungarian Agricultural Engineering, 30, 46-53, http://dx.doi.org/10.17676/HAE.2016.30.46

[14] Menyah, K., Wolde-Rufael, W. (2010) $\mathrm{CO}_{2}$ emissions, nuclear energy, renewable energy and economic growth in the US. Energy Policy, 38 (6), 2911-29-15, http://dx.doi.org/10.1016/j.enpol.2010.01.024

[15] Sims, R. E. H., Rogner, H. H., Gregory, K. (2003) Carbon emission and mitigation cost comparisons between fossil fuel, nuclear and renewable energy resources for electricity generation. Energy Policy, 31 (13), 13151326, http://dx.doi.org/10.1016/S0301-4215(02)00192-1

[16] Grambow, B., Landesman, C., Ribet, S. (2014) Nuclear waste disposal: I. laboratory simulation of repository properties. Applied Geochemistry, 49, 237-246, http://dx.doi.org/10.1016/j.apgeochem.2014.05.017

[17] Sarkar, A., Singh, J. (2010) Financing energy efficiency in developing countries-lessons learned and remaining challenges. Energy Policy, 38 (10), 5560-5571, http://dx.doi.org/10.1016/j.enpol.2010.05.001

[18] Boon, F. P., Dieperink, C. (2014) Local civil society based renewable energy organisations in the Netherlands: Exploring the factors that stimulate their emergence and development. Energy Policy, 69, 297-307, http://dx.doi.org/10.1016/j.enpol.2014.01.046

[19] Pauli, G. A. (2010) The Blue Economy: 10 Years, 100 Innovations, 100 Million Jobs. Paradigm Publications, p. 336

[20] Johnson, M., Christensen, C., Kagermann, H. (2008) Reinventing your business model. Harvard Business Review, 86 (12) 50-59 
[21] Schaltegger, S., Lüdeke-Freund, F., Hansen, E. (2012) Business cases for sustainability: the role of business model innovation for corporate sustainability. International Journal of Innovation and Sustainable Development, 6 (2), 95-119, http://dx.doi.org/10.1504/IJISD.2012.046944

[22] Schaltegger, S., Hansen, E., Lüdeke-Freund, F. (2016) Business Models for Sustainability: Origins, Present Research, and Future Avenues. Organization \& Environment, $29 \quad$ (1), 3-10, http://dx.doi.org/10.1177/1086026615599806

[23] Vansintjan, D. (2015) The energy transition to energy democracy - Power to the people. REScoop 20-20-20 Project Report. Co-funded by the Intelligent Energy Europe Programme of the European Union. pp. 76. Link: https://rescoop.eu/system/files/downloads/REScoop\%20Energy\%20Transit ion\%20to\%20Energy\%20Democracy\%20-\%20English.pdf

[24] Morris, C., Pehnt, M. (2012) Energy Transition - The German Energiewende. Heinrich Böll Stiftung. p. 112, Link: https://book.energytransition.org/sites/default/files/downloads2016/book/German-Energy-Transition_en.pdf

[25] Sáfián, F., Munkácsy, B. (2015) A decentralizált energiarendszer és a közösségi energiatermelés lehetöségei a településfejlesztésben Magyarországon. Földrajzi közlemények, 139 (4), 257-272, Link: http://www.foldrajzitarsasag.hu/downloads/foldrajzi_kozlemenyek_2015_1 39_evf_4_pp_257.pdf

[26] Huybrechts, B., Mertens, S. (2014) The relevance of the cooperative model in the field of renewable energy. Annals of Public and Cooperative Economics, 85 (2), 193-212, http://dx.doi.org/10.1111/apce.12038

[27] Butler, J., Docherty, P. (2012) Securing the Benefits of Wind Power in Scotland: A new concept for community benefit provision. - Research Report. Vento Ludens Ltd \& Docherty Consulting Ltd., Edinburgh. p. 78, Link: http://www.all-energy.co.uk/_novadocuments/28619

[28] Rae, C., Bradley, F. (2012) Energy autonomy in sustainable communities a review of key issues. Renewable and Sustainable Energy Reviews, 16 (9), 6497-6506, http://dx.doi.org/10.1016/j.rser.2012.08.002

[29] Walker, G., Simcock, N. (2012) Community Energy Systems. - In. Smith, M. J., Elsinga, M., O’Mahony, L. F., Ong, S. E., Wachter, S., Lowell, H. (eds.): International Encyclopedia of Housing and Home. Elsevier, Oxford. pp. 194-198

[30] Darby, S. (2010) Smart metering: what potential for householder engagement? Building Research \& Information. Special Issue: Housing occupancy feedback: linking behaviours and performance, 38 (5), 442-457, http://dx.doi.org/10.1080/09613218.2010.492660 
[31] Granström, P., Jackson, J. A., Denda, R., Gomez, A., Perez, J. A. R., Baron, M., Micheli, G., Cagno, E., Mauri, G., Goni, A. (2014) Steering the implementation of smart metering solutions throughout Europe, Meter On $7^{\text {th }}$ Framework Programme of the European Commission project, Final report. Link: http://www.meter-on.eu/file/2014/10/MeterON\%20Final\%20report-\%200ct\%202014.pdf

[32] Vadacchino, V., Denda, R., Fantini, G. (2013) First results in Endesa smart metering roll-out. Electricity Distribution (CIRED 2013), $22^{\text {nd }}$ International Conference and Exhibition $10-13^{\text {th }}$ of June, 2013, Stockholm, http://dx.doi.org/10.1049/cp.2013.0850

[33] Farhangi, H. (2010) The path of the smart grid. IEEE Power and Energy Magazine, 8 (1), 18-28, http://dx.doi.rg/10.1109/MPE.2009.934876

[34] Aman, S., Frincu, M., Chelmis, C., Noor, M., Simmhan, Y., Prasanna, V. K. (2015) Prediction models for dynamic demand response: Requirements, challenges, and insights. 2015 IEEE International Conference on Communications (SmartGridComm), http://dx.doi.rg/10.1109/SmartGridComm.2015.7436323

[35] Yoon, J. H., Baldick, R., Novoselac, A. (2014) Dynamic demand response controller based on real-time retail price for residential buildings. IEEE Transactions on Smart Grid, 5 (1), 121-129, http://dx.doi.org/10.1109/TSG.2013.2264970 